\title{
The Role of Corporate Taxation in a Large Welfare State
}

\author{
Christian Keuschnigg ${ }^{a}$
}

JEL-Classification: F21, H21, H53, J64, J65.

Keywords: corporate tax, foreign direct investment, unemployment, welfare state.

\section{Introduction}

Globalization puts pressure on the welfare state in high wage economies. Firms can escape domestic wage pressure by outsourcing labor intensive components to low wage economies or entirely relocating production by outbound foreign direct investment (FDI). The policy problem is that the need to raise tax revenue from mobile companies and the wage pressure resulting from the welfare state reinforce these strategies, thereby eroding the tax base and the financial viability of the welfare state. It is widely recognized that the corporation tax as a source tax importantly affects FDI by its impact on the location choice of firms. The high replacement income available in the welfare state might prop up wages too and similarly drive out investment to alternative locations. These arguments are supported by substantial empirical evidence (see Keuschnigg, 2009, for a review): (i) Firms tend to locate production in countries with a low tax burden. In fact, investment is particularly responsive on the extensive (FDI) margin; (ii) The corporate tax has a large effect on entry and entrepreneurship; (iii) Wages influence location decisions of multinationals as well, possibly even more than taxes; (iv) Wage taxes and high benefits in Europe (replacement rates are mostly 60\% or more, see NiCKELL, 1997) significantly inflate wages; (v) High labor costs boost outsourcing and FDI.

Existing theory has largely ignored the interaction of corporate taxation and welfare state policies. This is the focus of the present paper. Borrowing from Keuschnigg (2008) and Keuschnigg and Ribi (2009), a model of search unemployment and discrete location choice is proposed. The main results are four:

a University of St. Gallen (IFF-HSG), CEPR and CESifo. Address: IFF-HSG, Varnbuelstrasse 19, CH-9000 St. Gallen, Switzerland. Email: christian.keuschnigg@unisg.ch. I am grateful to seminar participants at the annual meeting of the Swiss Economic Association 2009 for helpful comments. 
(i) The optimal size of the welfare state depends on the degree of risk-aversion and unemployment rate as a measure of labor income risk; (ii) Corporate taxation and social insurance can have equivalent effects on unemployment and outbound FDI; (iii) While a tax increase can raise corporate tax revenue, it is rather likely to worsen the total fiscal stance; (iv) A corporate tax should be used to contribute to welfare state financing only in exceptional cases. A positive corporation tax could usefully complement the tax financed insurance scheme only if there is excessive job creation and inefficiently low unemployment, if the optimal size of the welfare state is small, and if the government has a strong redistributional objective. These conditions are probably not very realistic in European countries with high structural unemployment rates and large welfare states.

\section{The Model}

There is a mass one of risk-averse workers who are initially unemployed and search for a job. Expected utility is

$$
V_{L}=e(\theta) \cdot u(w-t)+(1-e(\theta)) \cdot u(b+h) .
$$

Workers earn a wage $w$ and pay a wage tax $t$. When unemployed, they collect benefits $b$ and enjoy the money equivalent value $h$ of leisure. The employment probability $e$ is equal to the ex post employment rate, and depends on labor market tightness $\theta$. It is determined in equilibrium but is taken as given by individuals. The concavity of the utility function reflects risk aversion, $u^{\prime}>0>u^{\prime \prime}$. The participation tax rate $t^{*} \equiv(t+b) / w$ in the sense of SAEZ (2002) measures the total fiscal burden imposed on the worker when switching from unemployment into a job. Since it consists of the sum of the wage tax and the foregone social benefits, it tends to be very high.

The timing of firm and worker decisions is: (i) free entry of firms; (ii) choice of production location and location specific investment; (iii) job search by workers and locally operating firms; (iv) matching and wage bargaining; (v) production and income payments. Entry means that investors incur a start-up cost $r$ in stage (i) which allows them to draw an investment project of type $q^{\prime} \in[0,1]$ from the distribution

$$
G(q)=\int_{0}^{q} g\left(q^{\prime}\right) d q^{\prime}
$$


where $q^{\prime}$ is the project specific success probability. The type $q^{\prime}$ reflects the firm's luck in its innovation effort. After learning its type $q^{\prime}$, the firm chooses the plant location before the investment risk is resolved. Investment succeeds or fails with probability $q^{\prime}$ at the end of stage (ii). If the firm fails, it closes down.

To set up production, firms must thus incur a risky investment $i$. The size of this investment is location specific and, importantly, is assumed to be larger abroad than at home. The firm must spend additional resources to prepare foreign production, adjust to different regulations and institutions etc. For simplicity, we normalize to zero the fixed cost at home so that $i$ is the differential investment required when setting up production abroad. After success or failure is realized, firms are homogeneous within each group.

A firm consists of a fixed number of vacancies $l$. Due to mismatch of skills and required job qualifications, hiring is subject to search frictions. The firm's workforce is $m l$ since, depending on market tightness, only a fraction $m$ of its vacancies are successfully filled. Ignoring other search costs, expected cash-flow per domestic firm is

$$
\pi=(y-w) \cdot m(\theta) l,
$$

where $y$ is output of the match and $y-w$ is the firm's job rent. The worker's job rent is $w-t-b-h=\left(1-t^{*}\right)-h$ and is diminished by the participation tax, reflecting wage tax and unemployment benefits. Standard Nash bargaining determines a wage $w=\gamma y+(1-\gamma)(t+b+h)$ which rises with the workers' bargaining power $0<\gamma<1$. A key aspect of wage formation is that taxes and unemployment benefits get partly shifted to firms. A higher wage thus reduces job creation and employment.

Instead of producing at home, firms can relocate, earning a profit abroad and repatriating dividends of $\pi_{f}$ A domestic investor of type $q^{\prime}$ sets up production locally if expected net present value exceeds the alternative value of locating abroad, $(1-\tau) \pi \cdot q^{\prime}>\pi_{f} \cdot q^{\prime}-i$, where $\tau$ is the corporate tax and $\pi_{f}$ is the cashflow and repatriated dividend of the foreign subsidiary, net of foreign corporation tax. We assume that the home country applies the exemption method and levies no further tax on foreign source profits. The exemption method is the most commonly applied method in OECD countries. We do not explicitly model the foreign economy but take $\pi_{f}$ to be larger than net of tax cash-flow earned at home. Given the differential investment cost, it is too costly for unprofitable firms (those with a low success probability) to go multinational. The pivotal firm is 


$$
q=\frac{i}{\Delta \pi}, \Delta \pi \equiv \pi_{f}-(1-\tau) \pi>0 .
$$

High benefits and wage taxes in the welfare state inflate wages and, in turn, reduce cash-flow $\pi$ from domestic activity. Given fixed $i$ and $\pi_{f}$, firms find it more profitable to relocate abroad and collect repatriated dividends $\pi_{f}$, instead of earning $\pi$ at home. A larger fraction of firms chooses outbound FDI. A higher corporate tax has the same effect by directly reducing net of tax cash-flow from domestic production.

Prior to entry, firms expend innovation effort, giving rise to an entry cost $r$. Innovation results in an investment project of type $q^{\prime}$ with probability $g\left(q^{\prime}\right)$. Ex ante, the probabilities of surviving and staying local or relocating are

$$
s=\int_{0}^{q} q^{\prime} d G\left(q^{\prime}\right), s_{f}=\int_{q}^{1} q^{\prime} d G\left(q^{\prime}\right), I=\int_{q}^{1} i d G\left(q^{\prime}\right) .
$$

All firms incur the entry cost but only part of them survive to production stage, $s+s_{f}<1$.

There is a mass one of risk-neutral investors who are endowed with entrepreneurial skills and one unit of wealth. Workers lack the managerial ability to run a firm, and have no own wealth which is consistent with the observed wealth concentration. The expected value of a firm is

$$
\pi_{e}=\int_{0}^{q}(1-\tau) \pi q^{\prime} d G\left(q^{\prime}\right)+\int_{q}^{1}\left(\pi_{f} q^{\prime}-i\right) d G\left(q^{\prime}\right) .
$$

To start a new firm, an entrepreneur must invest her entire wealth and, in addition, incurs a managerial effort cost. Investors differ with respect to their entrepreneurial ability which is uniformly distributed in $n \in[0,1]$. Suppose effort cost $r(n)$ satisfies $r(0)=0$ and $r^{\prime}(n)>0$. Type $n$ sets up a firm only if $\pi_{e}-r(n)>1$, where the alternative is not to invest wealth and avoid the effort cost. When not investing, these agents simply live off the endowment. The marginal agent $N$ is indifferent, leading to the free entry condition

$$
\pi_{e}=s \cdot(1-\tau) \pi+s_{f} \cdot \pi_{f}-I=1+r(N) .
$$


The expected net present value must cover the fixed entry cost, $\pi_{e} \geq 1+r$, reflecting the opportunity cost of capital and the initial innovation effort. Given a uniform distribution, the index for the marginal type is equal to the mass of firms created. With $N$ firms entering, a part $s N$ survives and stays local, earning $\pi$ gross of tax, and $s_{f} N$ plants are moved abroad. Corporate tax revenue amounts to $\tau \pi s N$.

Local firms and workers meet on a matching labor market. Skill mismatch leads to rationing so that only a fraction $m$ of vacancies and $e$ of workers get matched, leading to involuntary unemployment. The employment (hiring) probability rises (falls) with market tightness $\theta \equiv l s N$. The mass of job searchers is one so that tightness is equal to total vacancies. Finally, the government's budget constraint is $t e+\tau \pi s N=(1-e) b$. Output market equilibrium in the open economy follows by Walras' Law.

\section{Public Policy}

\subsection{Welfare State Reform}

A key function of the welfare state is to insure workers against unemployment when no insurance is available on private markets. Offering benefits and collecting contributions shifts income from the good to the bad state and smoothes income. However, higher benefits strengthen the workers' fallback position. Further, the wage tax gets partly shifted to employers as well. Social protection thus inflates wage costs and squeezes profits from domestic activity. The expected return on business creation declines. Not only is investment reduced, a larger part is shifted to foreign locations. National employment falls. The general equilibrium feedback reinforces this negative trend. As unemployment picks up and more tax payers turn into welfare recipients, the government suffers a double loss. It must spend more on social benefits and, at the same time, collects less wage tax revenue. The fiscal stance deteriorates in proportion to the participation tax $t^{*}$. Furthermore, when investment declines and a larger part of it is allocated to foreign locations, both the level and selection effects work to erode the national corporate tax base. The government must thus raise the wage tax even more to balance the budget. In the end, unemployment is up and the business sector not only scales down total investment but increasingly opts for outbound FDI.

On the positive side, workers enjoy better protection against job losses when benefits are more generous. Providing insurance to risk-averse individuals in the face of uninsurable labor income risk and missing private markets is a 
fundamental reason for the existence of the welfare state. At least a small level of social insurance is welfare increasing. The gains from insurance increase with the degree of relative risk-aversion, the size of the income gap between work and unemployment, and the unemployment rate $1-e$ as a measure of risk. Social spending should be expanded until the gains from insurance are offset by the increasing excess burden from welfare state financing. The excess burden shows up not only in the welfare system (proportional to the high participation tax $t^{*}$ ) but also in the corporate tax (proportional to the rate $\tau$ ). Since social insurance pushes up wages, it erodes profit per domestic firm, the number of firms located at home (reduced entry and a shift towards FDI both reduce national investment) and thereby erodes corporate tax revenue (see KeuschnigG, 2009, for a complete derivation of this and other results). To sum up: Expanding the welfare state boosts wages, cuts profits and reduces national investment and job creation due to reduced entry and a shift towards FDI. Unemployment rises. The optimal size of the welfare state depends on the degree of risk-aversion, the unemployment rate and the excess burden of tax financing (result i).

\subsection{Corporate Taxation}

The corporate tax directly reduces net profits which leads firms to shift towards FDI. A lower net domestic profit also reduces expected profit $\pi_{e}$ and discourages entry. Both the selection effect towards FDI and reduced entry diminish national job creation and raise unemployment. While a higher tax boosts corporate tax revenue, the impact on total fiscal stance is less clear when there is a larger welfare state. For each worker ending up unemployed, the government loses net tax revenue (net of social spending) in proportion to the participation tax $t^{*}$. While the tax raises more corporate tax revenue, it also triggers substantial losses in wage tax revenue and inflates welfare spending. Total fiscal stance may improve or deteriorate, leading to an ambiguous change in the wage tax.

Both corporate taxation and social insurance add to unemployment. To compare the relative impact, we ask: when raising the corporate tax by $\hat{\tau}$ percent, by how much must benefits be cut to prevent an increase in unemployment? Comparative static analysis yields $\hat{b}=-\left(1-t^{*}-h / w\right) e \cdot \hat{\tau}$ where $\hat{b} \equiv d b / w$, and $\hat{\tau} \equiv d \tau /(1-\tau)$. The bracket reflects the worker's job rent per unit of the wage, see the discussion of (2). Although the model is stylized, it points to an important trade-off. Suppose $\tau=0$ initially, then the budget $e t=(1-e) b$ implies $e t^{*}=b / w$. If unemployment is at $10 \%(e=9 / 10)$ and the replacement rate is $1 / 2$, a participation tax of $t^{*}=b /(w e)=5 / 9$ is needed, around $56 \%$. If the monetary valuation of leisure were zero $(b=0)$, then $\left(1-t^{*}\right) e=2 / 5$. If we introduced a 
corporate tax of $10 \%$, starting at a level of zero $(\hat{\tau}=d \tau=1 / 10)$, we would need to cut the replacement rate by $\hat{b}=d b / w=-2 / 50$ or 4 percentage points, from $50 \%$ to $46 \%$, to offset the impact of the tax. While there is always a trade-off between a higher corporate tax and larger benefits, the magnitude of this tradeoff is reduced if leisure value during unemployment were positive. On the other hand, unemployed workers might suffer from social stigma which could be associated with a negative value of $h$. We thus have the first part of result (ii): Raising the corporate tax by $\hat{\tau}$ percent and benefits by $\hat{b}=\left(1-t^{*}-b / w\right) e \cdot \hat{\tau}$ percent have the same effect on unemployment.

While it is recognized that the average corporate tax rate significantly affects FDI, the potential of the welfare state to influence FDI flows was not investigated to the same extent. How does the corporation tax compare with the welfare state to influence FDI? FDI reflects both a level (entry) and a composition effect. These two effects tend to offset each other so that national policy in general has an ambiguous impact on outbound FDI. Whatever the net effect, the same policy combination that keeps unemployment constant, also keeps net of tax profits and outbound FDI constant. The second part of result (ii) is, thus: Raising the corporate tax by $\hat{\tau}$ percent and benefits by $\hat{b}=\left(1-t^{*}-h / w\right) e \cdot \hat{\tau}$ percent have the same effect on outbound FDI.

Given missing insurance markets, the government should always protect workers. Hence, the corporation tax should be evaluated in the presence of a welfare state. To pin down the impact of the corporate tax on fiscal stance, Keuschnigg (2009) introduces a parameter $\eta^{*}$, satisfying $1>\eta^{*}>\eta$, where $\eta$ is the matching elasticity with respect to job searchers. This yields result (iii): Introducing a small corporate tax deteriorates the fiscal stance if the participation tax rate is large,

$$
t^{*}>(1-h / w) \frac{\left(1-\tau / \eta^{*}\right) \alpha}{1+\left(1-\tau / \eta^{*}\right) \alpha}, \alpha \equiv \frac{\eta^{*}}{1-\eta^{*}} \frac{1-\gamma}{\gamma}
$$

Suppose that workers are endowed with high bargaining power such that $\gamma=\eta^{*}>\eta$, and unemployment is inefficiently high (efficient unemployment requires $\gamma=\eta$, see Hosios, 1990). Then $\alpha=1$ holds. Starting from $\tau=h=0$, a small corporate tax reduces the fiscal stance if the participation tax rate is larger than a half $t^{*}>1 / 2$. Immervoll, Kleven, Kreiner and Saez (2007) report that participation tax rates are larger than $50 \%$ in most European countries. The condition could thus easily be fulfilled, meaning that an increase in the corporate tax rate could potentially worsen the total fiscal stance. The upshot is that one must also take into account the wage tax revenue and social spending. Given that 
the largest part of tax revenue in many countries is collected from wage income, and the largest part of public spending is for social purposes, the result could be important. The condition is even more likely to be fulfilled if the value of leisure $h$ is positive, and if the corporate tax rate is positive, and when the bargaining power of workers and, therefore, unemployment is inefficiently high.

Should the corporate tax be used at all to contribute to welfare state financing? One might conclude that a small corporate tax could be welfare increasing since its revenue can be used to cut the typically large participation tax. Given the results on the fiscal stance, it seems unlikely, although not impossible, that the corporate tax could play a useful role. An explicit welfare analysis reveals that the introduction of even a small corporate tax would be a Pareto inferior policy change if workers' bargaining power is strong and unemployment inefficiently high. So the corporate tax should not be used to contribute to welfare state financing, even if the participation tax is very high, pointing to a high tax distortion in wage taxation. But because the participation tax is high, the corporate tax also involves a very high excess burden which is seen not in the erosion of the corporate tax base but elsewhere in the system. It destroys jobs and thereby causes large fiscal losses due to lower wage tax revenue and inflated social spending. For this reason, the corporate tax involves a high excess burden even if its rate is small or zero.

A positive corporate tax rate could be rationalized if workers have weak bargaining power and unemployment is inefficiently low. Policy should then allow unemployment to rise. A low unemployment rate also means that little labor income risk is to be insured. If, in addition, the workers' risk-aversion is small, there is little demand for social insurance, implying small benefits, low wage taxes and small participation tax rates. The welfare state reduces entry and national job creation, as it should be with $\eta>\gamma$. When the optimal size of the welfare state is relatively small, the rise in unemployment might not be large enough. For efficiency reasons, the government could then levy a corporate tax to contain excessive job creation and restore an efficient unemployment rate. The gains accrue to workers while investors always loose. So the tax helps to redistribute from investors with financial wealth to workers subject to wage income risk. A high redistribution objective would then be another reason to have a positive corporate tax. We sum up with result (iv): If unemployment is inefficiently high, even a small corporate tax yields Pareto inferior welfare changes. A positive tax could be rationalized under strong a redistribution goal when unemployment is too low and demand for social insurance small. 


\section{Conclusions}

A major problem of the welfare state is the delocation of investment and the resulting loss of jobs. The purpose of the paper was to compare the consequences for employment and outbound FDI of corporate and labor taxes in the welfare state. The main results are that these policies are largely equivalent in their impact on unemployment and FDI. Based on an admittedly overly stylized back of the envelope calculation, we found that an increase in the corporate tax by 10 percentage points might have the same impact on unemployment and FDI than an increase in the replacement rate of unemployment insurance by 4 percentage points. Another result is that the corporate tax, while raising corporate tax revenue, could easily worsen a country's overall fiscal stance. By raising unemployment, it inflates social spending and erodes wage tax revenue. The excess burden of the corporate tax is therefore only to a minor extent due to the erosion of the corporate tax base but rather lies in the inflated cost of the welfare state. Even if it does raise enough revenue to improve the overall fiscal stance, the case for using the corporate tax in an advanced welfare state seems weak. Based on an explicit welfare analysis, we found that the corporate tax could play a useful role only if social insurance is optimally kept at a small scale, e.g. because of small risk-aversion, if the labor market is distorted towards excessive job creation, and if there is a strong desire to redistribute from investors to workers. One might conclude that these conditions are hardly fulfilled in European economies with high structural unemployment rates and a large welfare state.

\section{References}

Hosios, Arthur J. (1990), "On the Efficiency of Matching and Related Models of Search and Unemployment”, Review of Economic Studies, 57, pp. 279-298.

Immervoll, Herwig, Henrik J. Kleven, Claus T. Kreiner, and Emmanuel SAEZ (2007), "Welfare Reform in European Countries: A Microsimulation Analysis", Economic Journal, 117, pp. 1-44.

Keuschnigg, Christian (2008), "Exports, Foreign Direct Investment and the Costs of Corporate Taxation", International Tax and Public Finance, 15, pp. 460-477.

Keuschnigg, Christian (2009), "Corporate Taxation and the Welfare State", CESifo WP 2557 and University of St. Gallen, www.alexandria.unisg.ch/ Publikationen $/ 47460$. 
Keuschnigg, Christian and Evelyn Ribi (2009), "Outsourcing, Unemployment and Welfare Policy", Journal of International Economics, 78, pp. 168-176.

Nickell, Stephen (1997), "Unemployment and Labor Market Rigidities: Europe versus North America”, Journal of Economic Perspectives, 11, pp. 55-74.

Saez, Emmanuel (2002), "Optimal Income Transfer Programs: Intensive versus Extensive Labor Supply Responses”, Quarterly Journal of Economics, 117, pp. 1039-1073.

\section{SUMMARY}

In comparing the impact of corporate taxation and social insurance on foreign direct investment (FDI) and unemployment, the paper derives four main results: (i) the optimal size of the welfare state depends on the degree of risk-aversion, the unemployment rate and the excess burden of labor taxes. Unemployment partly reflects the country's exposure to globalization; (ii) corporate taxation and social insurance can have equivalent effects on unemployment and outbound FDI; (iii) while an increase in the corporate tax raises corporate tax revenue, it is likely to worsen total fiscal stance; (iv) a corporate tax should be used to contribute to welfare state financing only in exceptional cases. 